\title{
PENGARUH PERAN GANDA TERHADAP KINERJA KARYAWAN WANITA DI TEMPAT KERJA DI LPP RRI YOGYAKARTA
}

\author{
Oleh: Atik Dina Nasekhah, Universitas Negeri Yogyakarta \\ atyckdhina@gmail.com
}

\begin{abstract}
Abstrak
Penelitian ini bertujuan untuk mengetahui pengaruh peran ganda terhadap kinerja karyawan wanita di LPP RRI Yogyakarta. Penelitian ini termasuk ke dalam penelitian asosiatif kausal dengan menggunakan pendekatan kuantitatif. Sampel penelitian adalah seluruh pegawai yang berstatus PNS dan dinyatakan sudah atau pernah menikah di LPP RRI Yogyakarta sebanyak 63 pegawai wanita. Validitas menggunakan uji korelasi product moment dan reliabilitas menggunakan rumus cronbach alpha. Teknik pengumpulan data menggunakan kuesioner dan dokumentasi. Teknik analisis data dalam penelitian ini menggunakan analisis regresi sederhana. Hasil penelitian menunjukkan bahwa terdapat pengaruh negatif antara peran ganda terhadap kinerja karyawan di LPP RRI Yogyakarta. Hal ini ditunjukkan dari nilai signifikansi lebih kecil dari $0,05(0,000<0,05)$, dan koefisien regresi mempunyai nilai negatif sebesar -0,491. Artinya, semakin tinggi peran ganda maka akan semakin rendah kinerja karyawan wanita di LPP RRI Yogyakarta. Pada variabel peran ganda indikator yang dominan mempengaruhi peran ganda sebagai wanita pekerja di LPP RRI Nusantara II Yogyakarta yaitu indikator kurangnya keterlibatan sebagai istri dengan nilai rata-rata sebesar 15,98. Pada variabel kinerja karyawan indikator yang dominan mempengaruhi kinerja karyawan di LPP RRI Nusantara II Yogyakarta yaitu indikator kualitas keluaran dengan nilai rata-rata sebesar 15,63.
\end{abstract}

\section{Kata Kunci: peran ganda, kinerja karyawan}

\begin{abstract}
This study aims to determine the effect of double roles on the performance of female employees in LPP RRI Yogyakarta. This research belongs to causal associative research using a quantitative approach. The samples of this research were all employees with civil servant status and stated to have been married in LPP RRI Yogyakarta as many as 63 female employees. Validity of the data was using product moment correlation test and reliability using cronbach alpha formula. Data collection techniques used questionnaires and documentation. Data analysis technique in this study was using simple regression analysis. The results showed that there was a negative influence between the multiple roles on employee performance in LPP RRI Yogyakarta. This is shown from the significance value less than $0.05(0.000<0.05)$, and the regression coefficient has a negative value of -0.491. That is, the higher the double role will be the lower performance of female employees in LPP RRI Yogyakarta. In the double role variable the dominant indicator influences the double role as woman worker in LPP RRI Nusantara II Yogyakarta that is indicator of lack of involvement as wife with average value equal to 15,98. On employee performance variable dominant indicator influence employee performance in LPP RRI Nusantara II Yogyakarta that is output quality indicator with average value equal to 15,63 .
\end{abstract}

Keywords: dual role conflict, employee performance

\section{PENDAHULUAN}

Setiap manusia tentu memiliki kebutuhan hidup yang berbeda-beda.

Berbagai macam kebutuhan tadi harus dipenuhi agar dapat hidup dengan layak. Bekerja merupakan salah satu hal terpenting dalam kehidupan setiap manusia, karena dengan bekerja seseorang dapat memenuhi kebutuhan hidupnya.

Pada era globalisasi dimana segala informasi dapat diperoleh dengan mudah dan cepat, mendukung seseorang untuk 


\section{Diklus: Jurnal Pendidikan Luar Sekolah, 1(2), September 2017 - 142 Atik Dina Nasekhah}

meningkatkan efisiensi dan efektivitas pekerjaannya. Di dunia ketenagakerjaan khususnya, tidak hanya pria saja yang mempunyai kesempatan besar untuk menduduki posisi penting di suatu organisasi, bahkan wanita juga mempunyai kesempatan yang sama. Dibuktikan dengan banyaknya wanita yang mampu mengemban pekerjaan yang dulu hanya di sandang oleh pria saja.

Jumlah wanita dalam angkatan kerja meningkat dari 18 juta pada tahun 1950 ke 66 juta pada tahun 2000 (Mondy, 2010: 56). Dewasa ini, wanita mencapai 45 persen dari angkatan kerja. Riset dari Departemen Tenaga Kerja Wanita mengungkapkan bahwa wanita memegang setengah dari seluruh bidang pekerjaan manajemen profesional.

Departemen Tenaga Kerja A.S meramalkan bahwa pada 2013 pekerjaan yang tersedia akan melebihi jumlah karyawan sebesar 6,7 juta, dan pada 2030, pekerjaan yang tersedia akan melebihi jumlah karyawan sebesar 30 juta (Schuler, 2009: 55). Hasil ramalan ini tentu akan memberikan peluang yang besar bagi semua orang untuk mendapatkan pekerjaan. Wanita dalam angkatan kerja tentu akan meningkat pula dari tahun ke tahun.

Wanita telah membuktikan eksistensinya dalam dunia pekerjaan, tidak jarang banyak dari mereka yang memiliki peran ganda. Peran ganda wanita merupakan salah satu konsep yang ditawarkan oleh dunia ketenagakerjaan beberapa tahun ini. Di era pembangunan dewasa ini, banyak wanita yang mengembangkan karir dengan bekerja diluar rumah.

Pada saat wanita menjalani karirnya wanita juga dituntut untuk dapat berperan sebagai istri, serta ibu yang mengasuh dan merawat anak. Hal lumrah bagi wanita zaman sekarang ketika ia memiliki peran ganda. Dari semua wanita yang memiliki peran ganda, ada yang bisa menikmati 'peran berganda' itu, namun ada juga yang merasa sukar sehingga akhirnya banyak persoalan rumit semakin berkembang dalam kehidupan sehari-hari. Meskipun ada perubahan status, tanggung jawab primer untuk mengelola kegiatan rumah dan keluarga serta beristirahat bagi wanita yang memiliki peran ganda tetaplah ada, bahkan ketika dia bekerja penuh waktu di luar rumah (Fox, 2009: 227).

Fenomena keluarga dwi-karir yang merupakan situasi dimana suami maupun istri memiliki pekerjaan dan tanggung jawab, memberikan tantangan dalam organisasi. Berbagai macam keadaan yang terjadi dapat menimbulkan keterbatasan waktu bagi kedua belah pihak. Hal ini memunculkan tekanan karena wanita yang bekerja bukan timbul dari keinginan diri sendiri, seolah-olah tidak punya pilihan lain demi membantu ekonomi rumah tangga.

Biasanya, para ibu yang mengalami masalah demikian, cenderung merasa amat 


\section{Diklus: Jurnal Pendidikan Luar Sekolah, 1(2), September 2017 - 143 Atik Dina Nasekhah}

letih (terutama secara psikologi), karena sehari-hari memaksakan diri untuk bertahan di tempat kerja yang mungkin saja kurang disukainya. Dengan berbagai macam aktivitas yang dilakukan di tempat kerja maupun di rumah, pengelolaan waktu menjadi salah satu hal yang penting. Bagi beberapa orang karyawan wanita, keterbatasan waktu dan kelelahan fisik menjadi salah satu akibat adanya peran ganda.

Di Indonesia pada khususnya, peran ganda lebih banyak dimiliki oleh kaum wanita. Wanita yang memiliki peran ganda, cenderung akan memiliki waktu yang lebih terbatas, sehingga ia harus membagi waktu dengan baik antara pekerjaan dan keluarga. Pembagian waktu tadi terkadang memunculkan konflik interrole, dimana wanita yang sudah menikah dan bekerja harus melakukan dua peran berbeda yang menuntutnya untuk dapat menjalani keduanya dengan baik.

Wanita-wanita yang memilih konsentrasi berkarir, cenderung kurang perhatian dengan keluarga dan perannya di rumah sebagai ibu rumah tangga. Aldous (2009: 186) menyatakan bahwa pekerjaan bagi seorang wanita dalam perkawinan dualkarier menghasilkan dwi karir atau pergeseran ganda baginya, yang dibayar dalam angkatan kerja dan lainnya dalam peran yang sama menuntut sebagai ibu rumah tangga. Keduanya itu merupakan masalah dari peran ganda yang biasanya telah dibingkai sebagai masalah seorang wanita dalam menyeimbangkan pekerjaan dan keluarga.

Konflik peran yang dihadapi seorang karyawan memiliki dampak terhadap kinerja karyawan tersebut. Meski dalam beberapa kasus konflik dapat meningkatkan kinerja karyawan, namun pada umumnya karyawan yang memiliki konflik umumnya tidak fokus dalam mengerjakan pekerjaannya, hal ini akan mempengaruhi kinerja mereka.

Di setiap perusahaan ataupun organisasi tentu memiliki standar kinerja yang berbedabeda. Dalam evaluasi kinerja, ada standar yang disebut sebagai standar kinerja (performance standard). Evaluasi kinerja tidak mungkin dapat di laksanakan dengan baik tanpa standar kinerja. Esensi evaluasi kinerja adalah membandingkan kinerja ternilai dengan standar kinerjanya. Jika evaluasi kinerja dilaksanakan tanpa standar kinerja, hasilnya tidak mempunyai nilai (Wirawan, 2009: 65).

Pada kasus yang dialami oleh karyawati di LPP RRI Yogyakarta diketahui bahwa wanita ingin tetap bekerja, karena pekerjaan memberikan banyak arti bagi diri mulai dari dukungan finansial, mengembangkan pengetahuan dan wawasan, memungkinkan aktualisasi kemampuan, memberikan kebanggaan diri dan kemandirian meskipun penghasilan suami mencukupi, serta 


\section{Diklus: Jurnal Pendidikan Luar Sekolah, 1(2), September 2017 - 144 Atik Dina Nasekhah}

memungkinkan subyek mengaktualisasikan aspirasi pribadi lain yang mendasar seperti memberi rasa "berarti" sebagai pribadi, meskipun keterlibatan dalam berbagai peran ini dapat memberikan keuntungan psiko sosial, seperti peningkatan kepercayaan diri dan moral.

Menjalani dua peran sekaligus, sebagai seorang pekerja sekaligus sebagai ibu rumah tangga, tidaklah mudah. Karyawan wanita yang telah menikah dan punya anak memiliki peran dan tanggung jawab yang lebih berat dari pada wanita single. Peran ganda pun dialami oleh wanita tersebut karena selain berperan di dalam keluarga, wanita tersebut juga berperan di dalam karirnya. Konflik pekerjaan-keluarga menjelaskan terjadinya benturan antara tanggung jawab pekerjaan dirumah atau kehidupan rumah tangga.

Pada kenyataannya peran ganda memberikan konsekuensi yang berat. Di satu sisi wanita mencari nafkah untuk membantu suami bahkan pada kasus tertentu wanita lebih bisa diandalkan dalam menafkahi dan disisi lain wanita harus bisa melaksanakan tanggung jawabnya sebagai istri dan ibu. Walaupun demikian peran ganda wanita bukan pilihan yang tidak mungkin diambil dan hal tersebut sering berdampak kepada sikap mereka terhadap pekerjaan. Wanita karir karena keterbatasan waktunya, tidak mungkin bagi dirinya untuk sekaligus menjadi ibu rumah tangga secara maksimum.
Peran ganda yang dialami oleh wanita karir dapat menyebabkan hambatan dalam pekerjaan. Peran ganda dapat membuat wanita sulit meraih sukses di bidang pekerjaan, keluarga dan hubungan interpersonal sekaligus. Bila tidak ingin seperti itu disarankan sebaiknya wanita tersebut tidak berprinsip sebagai wanita super yang sanggup melakukan semuanya sendiri.

Ketidakmampuan wanita karir dalam menyelesaikan konfliknya tersebut dapat menyebabkan mereka menampilkan sikap kerja yang negatif misalnya kurang motivasi dalam bekerja, kurang konsentrasi karena urusan keluarga, sehingga dengan demikian akan berpengaruh terhadap kinerja organisasi atau perusahaan secara keseluruhan.

Ibu yang bekerja di luar rumah harus bijaksana mengatur waktu. Bekerja untuk memenuhi kebutuhan keluarga memang sangat mulia, tetapi tetap harus diingat bahwa tugas utama seorang ibu adalah mengatur rumah tangga. Ibu yang harus berangkat bekerja pagi hari dan pulang pada sore hari tetap harus meluangkan waktu untuk berkomunikasi, bercanda, memeriksa tugastugas sekolah anaknya meskipun ibu sangat capek setelah seharian bekerja di luar rumah. Tetapi pengorbanan tersebut akan menjadi suatu kebahagiaan jika melihat anak-anaknya bertumbuh menjadi pribadi yang kuat dan stabil. 


\section{Diklus: Jurnal Pendidikan Luar Sekolah, 1(2), September 2017 - 145 Atik Dina Nasekhah}

Berdasarkan uraian di atas, pada kenyataannya peran ganda memberikan konsekuensi yang berat pada wanita yang bekerja. Disatu sisi wanita mencari nafkah untuk membantu suami dan kebutuhan ekonomi keluarga, serta disisi lain, wanita harus bisa melaksanakan tanggung jawabnya sebagai istri dan seorang ibu. Sebagai contoh karyawati yang meniti karir dari bawah karena memiliki prestasi menonjol mendapat promosi ke jenjang atau jabatan yang lebih tinggi namun dengan tekanan kerja dan tanggung jawab yang lebih berat.

Kemudian timbullah konflik dalam diri karyawati tersebut, apakah dia harus menerima jabatan yang baru dengan resiko kehilangan waktunya mengatur kehidupan rumah tangga dan berkumpul dangan keluarga ataupun menolak jabatan tersebut dengan alasan agar lebih mudah mengurusi kehidupan rumah tangganya. Pada akhirnya ketikdakmampuan wanita dalam mengelola konflik yang dihadapi dapat menyebabkan berbagai persoalan salah satunya yaitu menurunnya kinerja karyawan tersebut.

Mondy (2008) mengemukakan "kinerja adalah suatu hasil kerja yang dicapai seseorang dalam melaksanakan tugas-tugas yang dibebankan kepadanya yang didasarkan atas kecakapan, pengalaman dan kesungguhan serta waktu". Bagi wanita pekerja dan telah berkeluarga akan memiliki kinerja yang berbeda dari wanita pekerja tetapi belum berkeluarga. Hal ini dikarenakan bagi ibu pekerja, mereka harus menjalani dua peran yang berbeda yakni menjadi wanita pekerja dan sebagai ibu rumah tangga, dan bagi ibu pekerja yang tidak dapat menjalaninya dengan baik akan mengalami konflik peran ganda.

Penelitian ini bertujuan untuk mengetahui pengaruh peran ganda terhadap kinerja karyawan wanita di LPP RRI Yogyakarta.

\section{METODE PENELITIAN}

\section{Jenis Penelitian}

Jenis penelitian ini adalah asosiatif kausal dengan menggunakan pendekatan kuantitatif. Penelitian asosiatif kausal adalah penelitian yang bertujuan untuk mengertahui pengaruh antara dua variabel atau lebih (Sugiyono, 2011: 36-37).

\section{Tempat dan Waktu Penelitian}

Lokasi penelitian berada di LPP RRI Yogyakarta. Penelitian dimulai saat awal observasi yaitu pada April 2017 sampai dengan siap untuk diklarifikasi pada bulan Juni 2017.

\section{Populasi dan Sampel Penelitian}

Populasi dan sampel dalam penelitian ini adalah seluruh pegawai wanita di LPP RRI Yogyakarta yang dinyatakan sudah menikah atau sudah pernah menikah yaitu 63 pegawai.

Teknik Pengumpulan Data dan Teknik Analisis Data 
Diklus: Jurnal Pendidikan Luar Sekolah, 1(2), September 2017 - 146

Atik Dina Nasekhah

Instrumen pengumpulan data menggunakan angket. Teknik analisis data menggunakan analisis regresi sederhana.

\section{HASIL PENELITIAN DAN PEMBAHASAN Hasil Penelitian}

Hasil analisis data penelitian akan diuraikan sebagai berikut:

\section{Peran Ganda}

Berdasarkan hasil analisis data diketahui bahwa peran ganda karyawan di LPP RRI Yogyakarta berada pada kategori tinggi sebanyak 27 responden $(42,86 \%)$. Adapun penggambaran histogramnya sebagai berikut.

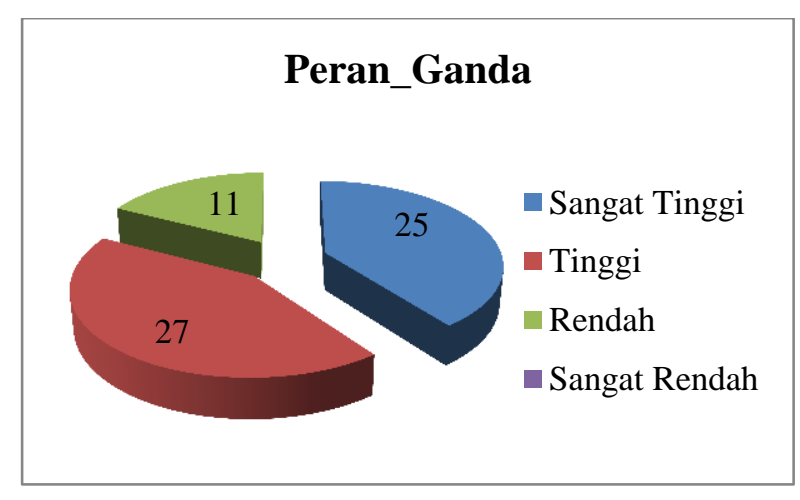

Gambar 1. Pie Chart Variabel Peran Ganda

\section{Kinerja karyawan}

Berdasarkan hasil analisis data diketahui bahwa kinerja karyawan di LPP RRI Yogyakarta berada pada kategori sangat tinggi sebanyak 33 responden $(52,38 \%)$. Adapun penggambaran histogramnya sebagai berikut.

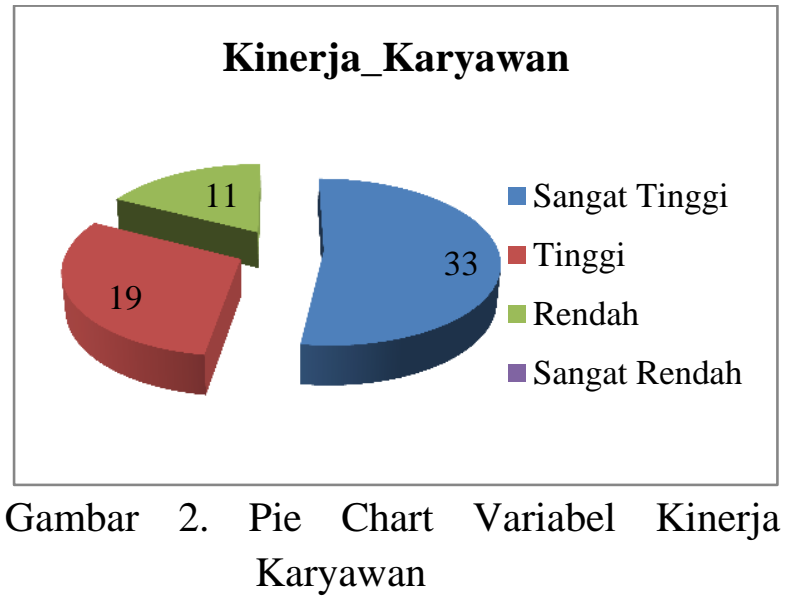

\section{Pembahasan}

Hasil penelitian menunjukkan bahwa antara peran ganda berpengaruh negatif terhadap kinerja karyawan di LPP RRI Yogyakarta. Hal ini ditunjukkan dari nilai signifikansi 0,000; dimana signifikansi lebih kecil dari $0,05(0,000<0,05)$, dan koefisien regresi mempunyai nilai negatif sebesar 0,491 .

Peran ganda muncul ketika seorang individu menjalankan posisi yang berbeda dari organisasi atau kelompok dalam waktu yang bersamaan. Sebagai contoh peran ganda, yaitu seseorang yang memiliki tanggung jawab di tempat kerja, tetapi juga bertanggung jawab di rumah. Wanita dengan peran ganda dituntut untuk berhasil dalam dua bidang yang bertentangan. Wanita yang memliki peran ganda akan bertemu dengan konflik-konflik yang timbul akibat pilihan yang sulit.

Berdasarkan temuan penelitian diketahui bahwa indikator yang dominan mempengaruhi peran ganda sebagai wanita pekerja di LPP RRI Nusantara II Yogyakarta 


\section{Diklus: Jurnal Pendidikan Luar Sekolah, 1(2), September 2017 - 147 Atik Dina Nasekhah}

yaitu indikator kurangnya keterlibatan sebagai istri dengan nilai rata-rata sebesar 15,98. Dalam hal ini kurangnya keterlibatan sebagai istri ditunjukkan dari merasa tidak dapat bekerja secara optimal karena memikirkan anak-anak di rumah, merasa bersalah bila suami harus menggantikan mengasuh anak bila terpaksa lembur di tempat kerja, merasa bersalah karena tidak bisa menyiapkan sarapan untuk keluarga, merasa bersalah kepada suami bila terpaksa terlambat pulang kerja, dan merasa tidak puas dengan kurangnya waktu kebersamaan dengan suami.

Pada variabel kinerja karyawan diketahui bahwa indikator yang dominan mempengaruhi kinerja karyawan di LPP RRI Nusantara II Yogyakarta yaitu indikator kualitas keluaran dengan nilai rata-rata sebesar 15,63. Hal ini ditunjukkan dari belum mampu bekerja sesuai dengan kemampuan dengan memanfaatkan sumber daya dan potensi yang ada, belum mampu bekerja sesuai dengan keterampilan yang dimiliki, belum mampu mengerjakan tugas sesuai dengan kualitas yang diinginkan oleh perusahaan, belum mampu menyelesaikan pekerjaan dengan ketelitian tinggi, dan belum terampil dalam melaksanakan pekerjaan sesuai dengan tugas dan fungsi.

Peran ganda merupakan suatu kendala yang dialami perempuan sebagai seorang istri dan ibu rumah tangga yang dituntut untuk mengurus rumah tangga, namun disisi lain juga dituntut untuk bekerja dan mengembangkan karir sesuai dengan profesi. Konflik peran karyawati yang memiliki peran ganda berkaitan dengan faktor internal dan eksternal. Faktor internal yang mempengaruhi munculnya konflik dalam peran ganda adalah harapan-harapan yang ada pada diri wanita itu sendiri, yang mendasari seorang wanita berkeluarga untuk bekerja dan untuk membina karir, apa yang diharapkan dari pernikahannya.

Apabila karyawati yang sudah berkeluarga tidak dapat menjalankan peran antara keluarga dan pekerjaannya, akan berdampak pada proses pelaksanaan pekerjaannya yang kurang produktif sehingga karyawati tidak dapat berfungsi secara normal dan menjadi tidak seimbang. Tugas-tugas yang berkaitan dengan pekerjaan dan keluarga merupakan tugas yang sangat penting dan sulit, bahkan bagi orang dewasa telah mempunyai pengalaman kerja, telah menikah, dan telah menjadi orang tua, mereka masih tetap harus melakukan penyesuaian diri dengan peran-peran tersebut.

Pada dasarnya peran ganda karyawati yang sudah berkeluarga terdapat dampak positif dan negatif dilihat dari aspek kepengurusan rumah tangga. Dampak positif dalam sumbangan yang diberikan untuk pendapatan keluarga serta kemampuan untuk menguasai lingkungan, inovasi, produktivitas, 


\section{Diklus: Jurnal Pendidikan Luar Sekolah, 1(2), September 2017 - 148 Atik Dina Nasekhah}

ketepatan pengambilan keputusan, dan eksistensi harkat dan martabat kewanitaannya. Sedangkan dampak negatif terutama dalam pengaturan perilaku waktu dalam beban kerja sebagai ibu rumah tangga maupun pekerja.

Peran ganda pada pekerja wanita timbul karena seorang ibu sebagai wanita karir berusaha semaksimal mungkin untuk mendampingi anak-anak, berhasil mengurus rumah tangga, anak-anak serta suami, tetapi tetap dapat menyalurkan kebutuhan mereka sebagai makhluk sosial kebutuhan untuk bersosialisasi, tetap mampu mandiri dari segi keuangan, pengembangan wawasan, serta perasaan dihargai dan bangga saat mereka bekerja menjadi wanita karir, sehingga kondisi tersebut akan mempengaruhi kinerja karyawan wanita yang semakin rendah.

Pada perempuan yang bekerja mereka dihadapkan pada banyak pilihan yang ditimbulkan oleh perubahan peran dalam masyarakat, di satu sisi mereka harus berperan sebagai ibu rumah tangga yang tentu saja bisa dikatakan memiliki tugas yang cukup berat dan sisi lain mereka juga harus berperan sebagai wanita karir.

Keinginan untuk menjalankan kedua peran tersebut dengan sempurna, terkadang saling bertentangan satu dengan lain, sehingga dapat menimbulkan konflik pada wanita bekerja. Oleh karena itu untuk meminimalisir konflik peran ganda karyawan maka perusahaan lebih memperhatikan jam kerja karyawan wanita, yaitu dengan cara karyawan wanita dibatasi jam kerja lemburnya atau untuk shift malam untuk karyawan wanita ditiadakan, sehingga karyawan wanita dapat membagi waktu untuk mengurus keluarganya serta dapat bekerja dengan lebih baik.

\section{SIMPULAN DAN SARAN \\ SIMPULAN}

Berdasarkan hasil penelitian maka dapat disimpulkan bahwa terdapat pengaruh negatif antara peran ganda terhadap kinerja karyawan di LPP RRI Yogyakarta. Hal ini ditunjukkan dari nilai signifikansi lebih kecil dari $0,05(0,000<0,05)$, dan koefisien regresi mempunyai nilai negatif sebesar -0,491. Artinya, semakin tinggi konflik peran ganda maka akan semakin rendah kinerja karyawan wanita di LPP RRI Yogyakarta.

Pada variabel peran ganda indikator yang dominan mempengaruhi yaitu indikator kurangnya keterlibatan sebagai istri dengan nilai rata-rata sebesar 15,98. Pada variabel kinerja karyawan indikator yang dominan mempengaruhi kinerja karyawan di LPP RRI Nusantara II Yogyakarta yaitu indikator kualitas keluaran dengan nilai rata-rata sebesar 15,63.

\section{SARAN}

Berdasarkan hasil penelitian dan kesimpulan yang telah diuraikan di atas maka 
dapat diberikan beberapa saran sebagai berikut.

\section{Bagi Pihak LPP RRI Yogyakarta}

Pihak LPP RRI Yogyakarta lebih memperhatikan jam kerja karyawan wanita, yaitu dengan cara karyawan wanita dibatasi jam kerja lemburnya atau untuk shift malam untuk karyawan wanita ditiadakan, sehingga karyawan wanita dapat membagi waktu untuk mengurus keluarganya serta dapat bekerja dengan lebih baik.

\section{Peneliti Selanjutnya}

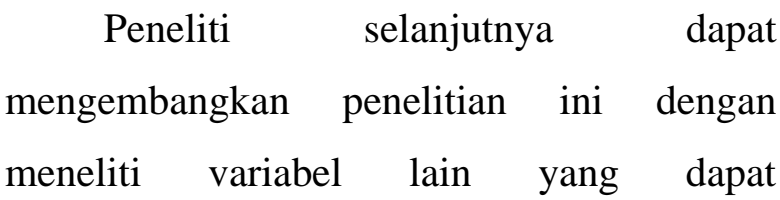
mempengaruhi kinerja karyawan misalnya stress kerja, dan komitmen organisasi. Peneliti selanjutnya juga dapat menggunakan metode lain dalam meneliti kinerja karyawan, misalnya melalui wawancara mendalam, sehingga informasi yang diperoleh dapat lebih bervariasi daripada angket yang jawabannya telah tersedia.

\section{DAFTAR PUSTAKA}

Aldous, C. R. 2007. Creativity, Problem Solving and Innovative Science Insights From History, Cognitive Psychology and Neuroscience. International Education Journal.

Fox, G; Schwartz, A; Hart, K.M. 2006. Work Family Balance And Academic Advancement In Medical Schools. Academic Psychiatry.

Mondy, R. Wayne. 2008. Manajemen Sumber Daya Manusia. Jakarta: Penerbit. Erlangga.
Schuler, R.S., Jackson, S.E., 1999. Strategic Human Resource Management: A Reader. Blackwell, London.

Sugiyono. 2011. Statistika Untuk Penelitian. Bandung: Alfabeta.

Wirawan. 2009. Evaluasi Kinerja Sumber Daya Manusia: Teori Aplikasi dan Penelitian. Jakarta: Salemba Empat. 